\title{
PENGARUH STRES PADA KESEHATAN JARINGAN PERIODONTAL
}

\author{
Ratih Larasati \\ Jurusan Keperawatan Gigi Poltekkes Surabaya \\ rlbaratajaya@gmail.com
}

\begin{abstract}
Stress is a psycho-physiological reactions to various stimuli emotionally or physically interfere with homeostasis, and can exacerbate diseases result from bacterial and viral infections in animals and humans. Psychological stress or psychosomatic conditions encourage the immunological changes. Namely stress hormone CRH, ACTH and glucocorticoids can affect the immune response resulting in bone loss, tissue damage, loss of attachment, and can inhibit wound healing. One of the periodontal pathogenic bacterial species is Porphyromonas gingivalis. Porphyromonas gingivalis bacteria found in dental plaque and bacteria that cause periodontal tissue pathological changes with the activation of the immune and inflammatory response of the host, and directly affects the cells of the periodontium. The high level of stress is accompanied by a lack of oral health can lead to more severe periodontal conditions.
\end{abstract}

Keywords: stress; periodontal; Porphyromonas gingivalis

\begin{abstract}
Abstrak. Stres adalah reaksi psiko-fisiologis terhadap berbagai rangsangan emosional atau fisik yang mengganggu homeostasis, dan dapat memperburuk penyakit akibat dari infeksi bakteri dan virus pada hewan dan manusia. Stres psikologis atau kondisi psikosomatik mendorong perubahan imunologi. Hormon stres yaitu $\mathrm{CRH}$, adeno cortiko tropin hormone $(\mathrm{ACTH})$ dan glukokortikoid dapat mempengaruhi respon imun yang mengakibatkan hilangnya tulang, kerusakan jaringan, hilangnya perlekatan, dan dapat menghambat penyembuhan luka. Salah satu spesies bakteri periodontal yang patogen yaitu Porphyromonas gingivalis. Bakteri Porphyromonas gingivalis banyak ditemukan dalam plak gigi. Bakteri tersebut menyebabkan perubahan patologik jaringan periodontal dengan pengaktifan respons imun dan inflamasi inang, dan secara langsung mempengaruhi sel-sel periodonsium. Tingkat stres yang tinggi disertai dengan kurangnya kesehatan mulut dapat menyebabkan kondisi periodontal yang lebih parah.
\end{abstract}

Kata kunci: stres; periodontal; Porphyromonas gingivalis

\section{Pendahuluan}

Tak seorangpun terbebas dari stres. Stres adalah suatu keadaan tekanan mental atau kecemasan yang disebabkan oleh masalah hidup, pekerjaan, dan lain-lain. ${ }^{1}$ Stres adalah reaksi psiko-fisiologis tubuh terhadap berbagai rangsangan emosional atau fisik yang mengganggu homeostasis, dan dapat mengeksaserbasi penyakit hasil dari infeksi bakteri dan virus pada hewan dan manusia. ${ }^{2}$ Menurut WHO (2003) dalam Sriati (2008), stres adalah reaksi atau respon tubuh 
terhadap stresor psikososial (tekanan mental atau beban kehidupan). Stres adalah respon manusia yang bersifat nonspesifik terhadap setiap tuntunan kebutuhan yang ada dalam dirinya (Pusdiknakes Depkes. RI dalam Sunaryo 2004). ${ }^{3}$

Berdasarkan jenisnya, stres dibagi menjadi dua yaitu stres negatif (distress) dan stres positif (eustress). Stres positif adalah kondisi seseorang yang mampu mereduksi ketegangan pada dirinya karena adanya motivasi atau dorongan-dorongan, baik bersifat internal atau eksternal. Misalnya stres yang dirasakan ketika akan menghadapi ujian akademik. Stres negatif adalah seseorang tidak mampu mereduksi ketegangannya yang akhirnya timbul dampak negatif, yaitu penyakit. ${ }^{4}$

Menurut Everly dan Girdano (1980), stress akan mempunyai dampak pada suasana hati (mood), otot kerangka (musculo skeletal), dan organ dalam tubuh (visceral). Tandatanda suasana hati (mood) adalah cemas, merasa tidak pasti, sulit tidur pada malam hari, suka lupa, dan gugup. Tanda-tanda muskuloskeletal adalah jari-jari dan tangan gemetar, kepala mulai sakit, leher kaku atau berdiri di tempat. Tanda-tanda visceral adalah tangan berkeringat, banyak berkeringat, jantung berdebar, perut terganggu, mulut kering, suara berdering dalam telinga. ${ }^{5}$

\section{Pembahasan}

Konsep stres

Menurut Elliot dan Eisdorfer (1982) taksonomi stres ada lima kategori stresor: a) Acute time-limited stressors melibat-kan tantangan di dalam laboratorium seperti berbicara di depan umum atau aritmatika mental; b) Brief naturalistic stressors, seperti ujian akademis, melibatkan orang yang sedang menghadapi tantangan jangka pendek dalam kehidupan nyatanya; c) Stressful event sequences, contoh kehilangan pasangan atau bencana alam besar, menimbulkan serangkaian tantangan terkait. Meskipun individu yang terkena biasanya tidak mengetahui persis kapan tantangan ini akan mereda, mereka yakin bahwa di masa depan mereka akan mampu, d) Chronic stressors, biasanya tentang hidup seseorang, memaksa dia untuk merestrukturisasi atau identitasnya atau peran sosial. Pada stresor kronis, individu yang mengalami tidak mengetahui kapan tantangan akan 
berakhir atau malah meyakini itu tidak akan pernah berakhir. Contoh stres kronis adalah cedera traumatis yang mengarah ke cacat fisik, memberikan perawatan untuk pasangan dengan demensia parah, atau menjadi pengungsi dipaksa keluar dari negara asal seseorang oleh perang; e) Distant stressors, stres karena pengalaman traumatis yang terjadi di masa lalu belum memiliki potensi untuk terus memodifikasi fungsi sistem kekebalan tubuh karena kognitif tahan lama dan gejala sisa emosional. Contoh stres jauh adalah kekerasan seksual pada anak, setelah menyaksikan kematian seorang teman seperjuangan selama pertempuran, dan telah menjadi tawanan perang. ${ }^{5}$

\section{Respon tubuh terhadap stres}

Stres didefinisikan sebagai stimulus eksternal yang kuat baik fisiologis dan psikologis yang menyebabkan respon fisiologis dalam tubuh seseorang. Oleh karena itu, stres dapat digambarkan sebagai proses dengan komponen fisiologis dan psikologis. Definisi psikologis dari stres dilihat dari cara seseorang merespon stres pada sejumlah faktor, termasuk kemampuan untuk menghadapi stres (coping), predisposisi genetik, stresor, tingkat dukungan sosial, dan faktor gaya hidup lainnya. Stresor adalah stimulus, situasi, atau keadaan dengan potensi menyebabkan reaksi stres.

Efek potensial respon stres yang dapat diobservasi atau diukur termasuk kecemasan, depresi, kognisi yang terganggu, dan kepercayaan diri terganggu. Definisi fisiologis stres adalah stres dapat menyebabkan deregulasi sistem imun, dimediasi oleh HPA axis dan sympatheticadrenal-medullary axis. Sebagai respon terhadap berbagai stimuli stres, terjadi inisiasi sekuens kejadian. Ketika situasi tertentu diinterpretasikan sebagai keadaan stres, hal ini akan memicu aktivasi hypothalamic-pituitary-adrenal (HPA) axis melepaskan hormon corticotropinreleasing hormone ( $\mathrm{CRH})$.

Pelepasan CRH memicu sekresi dan pelepasan hormon lain, yaitu adrenocorticotropin hormone(ACTH) dari kelenjar pituitary, yang juga terletak di otak. Ketika ACTH disekresi oleh kelenjar pituitary, hormon ini mengikuti aliran darah dan mencapai kelenjar adrenal, yang berada di atas ginjal, dan memicu sekresi hormon stres. Ada dua macam 
hormon stres utama, yaitu glukokortikoid (kortisol pada manusia) dan katekolamin (adrenalin dan nor adrenalin).

Sekresi akut glukokortikoid dan katekolamin sebagai respon terhadap adanya stresor merupakan mediator primer dalam rantai hormonal yang dipicu respon terhadap stres. Kedua hormon yang disekresi sebagai respon terhadap stres ini bertindak dalam tubuh untuk memberikan respon fight-or-flight menyebabkan peningkatan detak jantung dan tekanan darah. Glukokortikoid memiliki efek yang berbeda-beda pada sistem target, bertujuan untuk meningkatkan keberadaan substrat energi pada bagian tubuh yang berbeda, dan memberikan adaptasi optimal untuk menghadapi tuntutan lingkungan. Sedangkan aktivasi HPA axis dianggap sebagai mekanisme adaptasi dasar terhadap adanya perubahan, aktivasi berkepanjangan memberikan risiko pada kesehatan organisme.

Katabolik glukokortikoid yang tinggi melawan insulin dan meningkatkan tekanan darah sehingga meningkatkan risiko diabetes, hipertensi, dan penyakit arterial. Pertumbuhan dan perbaikan jaringan terganggu. Di sisi lain, aktivasi $H P A$ axis menekan fungsi imun, dan dalam keadaan kronis berbahaya bagi organisme karena berhubungan dengan peningkatan risiko terjadinya infeksi. ${ }^{6}$

Stres memiliki efek pada respon imun dan kerentanan terhadap infeksi. Sel inang (host), $\mathrm{T}$ limfosit dan makrofag merupakan sel-sel yang penting dalam pengaturan proses imun-inflamasi. Respon psikologis terhadap pemicu stres dapat mengubah sistem imun melalui sistem neural dan endokrin, respon akibat stres dihantarkan melalui tiga jalur yaitu ke aksis hyphotalamopituitary-adrenal (HPA) ke sistem saraf simpatik dan ke saraf sensonic peptidergic. Sebaliknya stres juga dapat menyebabkan aktivasi imun melalui berbagai jalur. CRF sendiri dapat merangsang pelepasan norepinefrin melalui reseptor CRF yang terletak di locus cereleus yang mengaktifkan sistem saraf simpatis, baik sentral maupun perifer, serta meningkatkan pelepasan epinefrin dari medulla adrenal. Di samping itu, terdapat hubungan langsung neuron norepinefrin yang bersinaps pada sel target imun. Dengan demikian, di 
dalam menghadapi stresor, juga terdapat aktivasi imun yang dalam termasuk pelepasan faktor imun humoral (sitokin) seperti IL-1 dan IL6. Sitokin dapat menyebabkan pelepasan CRF lebih lanjut, yang di dalam teori berfungsi untuk meningkatkan efek glukokortikoid sehingga membatasi sendiri aktivasi imun. ${ }^{2,5,10}$

Sel-sel sistem imun didistribusi di seluruh tubuh ketika infeksi terjadi, respon inflamasi yang menyusun elemen sistem imun pada area spesifik. Setelah proses infeksi menjadi kronis, inflamasi secara klinis terjadi, meningkatkan sitokin dan mediator inflamasi lain yang berhubungan dengan aktivasi dari sistem stres. Apabila reaksi inflamasinya bermakna dan bertahan lama, terjadi manifestasi berupa penyakit sistemik seperti rheumatoid arthritis dan penyakit periodontal. ${ }^{3,6}$

\section{Respon jaringan periodontal}

terhadap stres

Banyak hasil penelitian telah menunjukkan bahwa stres psikologis atau kondisi psikosomatik mendorong terjadinya perubahan imunologis. Peningkatan kadar kortisol dan epinefrin dapat mengganggu homeostasis dan meningkatkan kerentanan terhadap penyakit melalui berbagai mekanisme. Kortisol menyebabkan efek ant-inflamasi yang poten dan imunosupresif. Hal ini dibuktikan dengan administrasi kortisol dalam jumlah banyak mengurangi respon inflamasi terhadap infeksi. Mekanisme biologis stres mereduksi fungsi sistem imun, dan terjadinya inflamasi kronis dimediasi oleh produksi hormon kortisol yang mengurangi kemampuan imun dengan menghambat $\operatorname{IgA}$ dan $\mathrm{IgG}$ dan fungsi neutrofil, sehingga terjadi peningkatan kolonisasi biofilm dan berkurangnya kemampuan untuk mencegah invasi bakteri pada jaringan ikat.

Setelah terjadi peningkatan kortisol yang kronis, kortisol akan kehilangan kemampuannya untuk menghambat respon inflamasi yang diinisiasi oleh reaksi imun, sehingga destruksi inflamasi terjadi terus menerus pada jaringan periodontal mengakibatkan resorpsi tulang, kerusakan jaringan, kehilangan perlekatan, serta dapat menghambat penyembuhan luka. ${ }^{3,6}$ Hubungan 
antara penyakit periodontal dan faktor predisposisi psikososial dapat dilihat pada kasus acute necrotizing ulcerative gingivitis (ANUG). ${ }^{6,7,12}$

Bakteri Porphyromonas gingivalis

Salah satu spesies bakteri periodontal yang patogen yaitu Porphyromonas gingivalis. Porphyromonas gingivalis merupakan bakteri melanogenik, nonsakarolitik, dan bagian dari koloni bakteri Blackpigmented Gram-negative anaerobes. Bakteri Porphyromonas gingivalis banyak ditemukan dalam plak gigi yang menyebabkan perubahan patologik jaringan periodontal dengan pengaktifan respons imun dan inflamatori inang, dan secara langsung mempengaruhi sel-sel periodonsium. Porphyromonas gingivalis memproduksi berbagai faktor virulensi patogenik, seperti lipopolisakarida dan hidrogen sulfida, yang dapat menginduksi inang untuk melepaskan Interleukin-1 (IL-1) dan TNF- $\alpha .{ }^{8}$ Porphyromonas gingivalis (sebelumnya disebut Bacteroides gingivalis) adalah bakteri Gramnegatif anaerob yang diklasifikasikan dalam genus Porphyromonas, famili Porphyromo-nadaceae, order Bacte- roidales, klas Bacteroides, dan phylum Bacteroidates.

Bakteri yang sering ditemukan dalam poket periodontal yang dalam ini asaccharolytic dan sangat proteolitik. Pertumbuhan asaccharolytic tidak dipengaruhi oleh karbohidrat tapi sangat ditingkatkan oleh protein hydrolysates, seperti pepton atau yeast extract. Produk fermentasi mayornya berupa $n$ butyric dan acetic acid, sedangkan produk minornya terdiri dari propionic, isobutyric, isovaleric, dan kadang phenilacetic acids. Temperatur maksimal untuk pertumbuhan adalah $37^{\circ} \mathrm{C}$. pertumbuhan yang signifikan dapat dipengaruhi oleh adanya karbohidrat. Substrat nitrogenous seperti proteose peptone, trypticase dan ekstrak yeast dengan nyata dapat meningkatkan pertumbuhan Porphyromonas gingivalis (Leslie, C., et al., 1998). ${ }^{8,9}$

Patogenesis bakteri Porphyromonas gingivalis

Sebuah penelitian yang dilakukan Noril et al. (1997) mengatakan bahwa Porphyromonas gingivalis merusak jaringan dengan interaksi langsung antara bakteri dan sel inang. 
Ketika kontak langsung dengan epitel di sulkus periodontal, Porphyromonas gingivalis mampu menyerang berbagai jaringan host termasuk tulang alveolar. Faktor-faktor virulensi yang terlibat dalam kolonisasi jaringan akan dapat mengubah pertahanan jaringan host. $^{9,11}$

Porphyromonas gingivalis merupakan stimulator poten dari mediator inflamasi seperti Interleukin-1 (IL-1) dan Prostaglandin E2 yang akhirnya dapat menyebabkan resorbsi tulang (Cutler et al,1995). Porphyromonas gingivalis dapat memetabolisme asam amino dan menghasilkan sejumlah metabolit atau produk akhir yang bersifat toksik terhadap jaringan gingival pada manusia, juga berpengaruh terhadap perkembangan penyakit periodontal. ${ }^{8}$

\section{Upaya peningkatan kekebalan stres}

a) Makan dan minum hendaknya yang baik serta tidak berlebihan. Jadwal makan hendaknya teratur pagi, siang dan malam, dan diusahakan jangan sampai telat, b) Tidur merupakan kegiatan alamiah yang dapat memulihkan segala keletihan fisik dan mental. Tidur adalah kebutuhan mutlak bagi kehidupan mahluk hidup, terutama manusia; oleh karena itu jadwal tidur hendaknya teratur. Lamanya tidur yang baik adalah antara 7-8 jam dalam semalam, c) Untuk meningkatkan daya tahan dan kekebalan baik fisik maupun mental, olah raga adalah salah satu caranya, d) Tidak merokok adalah kebiasaan hidup yang baik bagi kesehatan dan ketahanan serta kekebalan tubuh, e) Menjaga kebersihan gigi dan mulut dengan cara menyikat gigi minimal dua kali sehari yaitu pagi setelah sarapan dan sebelum tidur malam, f) Tidak meminum keras (minuman yang mengandung alcohol) adalah kebiasaan hidup yang baik bagi kesehatan dan ketahanan serta kekebalan tubuh. ${ }^{4}$

\section{Simpulan dan Saran}

Saat stres muncul, kadar hormon kortisol akan meningkat, dan sistem kekebalan terganggu sehingga bakteri atau virus leluasa menyerang gingiva (gusi) atau mulut penderita. Stres bisa memicu seseorang untuk lebih banyak melakukan kebiasaankebiasaan yang merugikan rongga mulut, bahkan mungkin mengabaikan 
kesehatan mulutnya. Tingginya level stres disertai dengan kurangnya kesehatan rongga mulut dapat menimbulkan kondisi periodontal yang lebih parah. Hal ini ditandai dengan peningkatan kehilangan perlekatan, kehilangan tulang alveolar yang parah dan pendarahan pada gingiva yang meningkat. Stres psikologis juga dapat mempengaruhi keberhasilan dan jalannya perawatan penyakit periodontal.

Berdasarkan pembahasan di atas, maka disarankan agar stress dapat diatasi dengan cara yang tepat, dan tidak mengabaikan kebersihan gigi dan mulut, seperti menyikat gigi dengan baik dan teratur agar dapat mencegah terjadinya penyakit periodontal.

\section{Daftar Pustaka}

1. Hansen, F., 2014, How Does Stress Affect Your Immune System ?, http://adrenalinefatiguesolution.co $\mathrm{m}$ /stress-immune-system/ (diakses 22 Desember 2015)

2. Daliemunthe,S.H., Hubungan Stress Dengan Penyakit Dan Perawatan Periodontal, http://www.researchgate.net/publi cation/42349686_Hubungan_Stre ss_Dengan_Penyakit_Dan_Peraw atan_Periodontal [accessed Dec 8, 2015]

3. Yulikistan, tt, Bab II, http://digilib.unimus.ac.id/files/dis k1/132/jtptunimus-gdl-yulikistan6567-3-babii.pdf (diakses 20 Januari 2016)

4. Sitoresmi, D., 2011, Stres dan Mekanisme Adaptasi, http://www.berbagimanfaat.com/2 011/09/mekanisme-dan-respontubuh-terhadap.html (diakses 4 Januari 2016)

5. Segerstrom, S.C., dan Miller, G.E., 2004, Psychological Stress and the Human Immune System: A Meta-Analytic Study of 30 Years of Inquiry, NIH Public Access, Psychol Bull, 130(4): 601-630.

6. Hokardi, C.A., 2013, Pengaruh Stres Akademik Terhadap Kondisi Jaringan Periodontal dan Kadar Hormon Kortisol Dalam Cairan Krevikular Gingiva, Tesis, https://www.google.co.id/search? newwindow $=1 \& q=$ Pengaruh + Stre s+Akademik+Terhadap+Kondisi+ Jaringan+Periodontal+dan+Kadar +Hormon+Kortisol+Dalam+Caira $\underline{n+K r e v i k u l a r}+$ Gingiva\&oq $=$ Peng aruh+Stres+Akademik+Terhadap + Kondisi+Jaringan+Periodontal+ dan+Kadar+Hormon+Kortisol+D alam+Cairan+Krevikular+Gingiv a\&gs_l=serp.12...1781315.18169 36.0.1818927.28.22.2.4.4.0.232.2 038.12j6j1.19.0...0...1c.1.64.serp. 3.24.2000.Ea7u5o0HaMg (diakses 8 Desember 2015)

7. Dondy, 2009, Pengaruh Stres Terhadap Kesehatan Gigi dan Mulut, http://drgdondy.blogspot.co.id/20 09/06/pengaruh-stress-terhadapkesehatan-gigi.html (diakses 22 Desember 2015)

8. Kusumawardani, B., Pujiastuti, P., dan Sari, D.S., 2010, Uji Biokimia Sistem API 20 A Mendeteksi Porphyromonas 
gingivalis Isolat Klinik dari Plak Subgingiva Pasien Periodontitis Kronis, Jurnal PDGI, http://journal.pbpdgi.or.id/index.p hp/jpdgi/article/download/13/9 (diakses 27 Januari 2015)

9. NN, 2008, Porphyromonas gingivalis, https://mikrobia2.files.wordpress. com/2008/05/blog-mikro1.pdf (diakses 27 Januari 2015)

10. Elisa, tt, Sitokin Bab 7, http://elisa.ugm.ac.id/user/archive /download/24233/52040c128ab18 31760f6b4299f3b2d78 (diakses 27 Januari 2015)

11. Felisa, tt, Patogenesis Penyakit Periodontal, https://www.google.co.id/url?sa=t \& $\mathrm{rct}=\mathrm{j} \& \mathrm{q}=\& \mathrm{esrc}=\mathrm{s} \&$ source $=\mathrm{web}$ \&cd=7\&ved=0ahUKEwj2 fzBm8 vJAhUCHY4KHSvlDF8QFghC MAY\&url=http\%3A\%2F\%2Felis a.ugm.ac.id\%2Fuser\%2Farchive \%2Fdownload\%2F38187\%2Fe86 d1c32899e85908c9aac9155d8fe2 2\&usg=AFQjCNHCa17o0mJmq Oggz4tOPz0cK-7A6w (diakses 8 Desember 2015)

12. Iacopino, A.M., 2009, Relationship Between Stress, Depression and Periodontal Disease, JCDA - June 2009, Vol. 75, No. 5, www.cda-adc.ca/jcda 